Pesq. Vet. Bras. 37(8):859-865, agosto 2017

DOI: $10.1590 / \mathrm{S} 0100-736 \mathrm{X} 2017000800013$

\title{
Efficacy of a Kalanchoe gastonis-bonnieri extract to control bacterial biofilms and dental calculus in $\operatorname{dog} s^{1}$
}

\author{
Samira L. Abdalla ${ }^{2 *}$, Sônia S. Costa ${ }^{3}$, Marco Antônio Gioso ${ }^{2}$, Livia M. Casanova ${ }^{3}$, \\ Marcela A.S. Coutinho ${ }^{3}$, Marta Fernanda A. Silva ${ }^{4}$, Maria Clara da S.N. Botelho ${ }^{5}$ \\ and Raquel S.G. Dias ${ }^{6}$
}

\begin{abstract}
Abdalla S.L., Costa S.S., Gioso M.A., Casanova L.M., Coutinho M.A.S., Silva M.F.A., Botelho M.C.S.N. \& Dias R.S.G. 2017. Efficacy of a Kalanchoe gastonis-bonnieri extract to control bacterial biofilms and dental calculus in dogs. Pesquisa Veterinária Brasileira 37(8):859-865. Departamento de Cirurgia, Faculdade de Medicina Veterinária e Zootecnia, Universidade de São Paulo, Avenida Prof. Dr. Orlando Marques de Paiva 87, Cidade Universitária, São Paulo, SP 05508-270, Brazil. E-mail: pgcir@usp.br

An aqueous leaf extract of the medicinal species Kalanchoe gastonis-bonnieri (here denominated KGB) has been found to be effective as an antimicrobial agent against canine oral cavity bacteria in in vitro assays. In this study, we investigated the effect of topic oral administration of KGB on the development of dental biofilm in Beagle dogs. The experiments were performed with an experimental group ( $0.2 \%$ of KGB extract), a negative control group ( $0.9 \%$ of saline solution) and a positive control group $(0.12 \%$ chlorhexidine). Each treatment was sprayed into the oral cavity daily for 28 days. Thirty Beagle dogs with similar characteristics and kept under the same management and diet were used. The measurement of dental plaque and calculus was performed using a computerized analytical method. The phenolic profile of KGB extract was analyzed by HPLC-DAD. KGB extract at $0.2 \%$ showed efficacy in controlling the formation of plaque compared to the negative control group, and dental calculus in relation to the negative and positive control groups. A significant difference was observed among these three groups. Peaks attributed to flavonoids and phenolic acids were identified in the HPLC-DAD chromatogram of the KGB extract. The presence of these substances could be related to the activity observed. Our findings demonstrate that treatment with KGB is effective in controlling periodontal disease in dogs, providing new insights into the medicinal properties of this plant. KGB extract has a potential use as a supplemental agent in pharmaceutical products for the prevention of periodontal disease.
\end{abstract}

INDEX TERMS: Kalanchoe gastonis-bonnieri, plant extract, bacterial biofilm, dental calculus, dogs, periodontal disease, dental plaque, flavonoids.

\footnotetext{
${ }^{1}$ Received on June 29, 2015.

Accepted for publication on September 5, 2016.

${ }^{2}$ Departamento de Cirurgia, Faculdade de Medicina Veterinária e Zootecnia, Universidade de São Paulo (USP), Avenida Prof. Dr. Orlando Marques de Paiva 87, Cidade Universitária, São Paulo, SP 05508 270, Brazil. *Corresponding author: abdallasamira@hotmail.com

3 Instituto de Pesquisas de Produtos Naturais, Universidade Federal do Rio de Janeiro (UFRJ), Bloco H, Ilha do Fundão, Rio de Janeiro, RJ 21941902, Brazil.

${ }^{4}$ Departamento de Medicina e Cirurgia, Universidade Federal Rural do Rio de Janeiro (UFRRJ), Seropédica, RJ 23890-000, Brazil.

${ }^{5}$ Departamento de Parasitologia Animal, UFRRJ, Seropédica, RJ 23890-000, Brazil.

${ }^{6}$ Programa de Ciência Cardiovascular, Faculdade de Medicina, Universidade Federal Fluminense (UFF), Niterói, RJ 24033-900, Brazil.
}

RESUMO.- [Eficácia do extrato de Kalanchoe gastonis-bonnieri no controle do biofilme bacteriano e cálculo dentário em cães.] Um extrato aquoso de folhas da espécie medicinal Kalanchoe gastonis-bonnieri (aqui denominado como KGB) foi efetivo como um agente antimicrobiano contra as bactérias da cavidade oral de cães em testes in vitro. Neste estudo, investigou-se o efeito da administração oral tópica de KGB sobre o desenvolvimento do biofilme dental em cães da raça Beagle. Os experimentos foram realizados com um grupo experimental $(0,2 \%$ de extrato de KGB), um grupo controle negativo $(0,9 \%$ de solução salina) e um grupo controle positivo $(0,12 \%$ de gluconato de clorexidina). Cada tratamento foi aplicado no interior da ca- 
vidade oral diariamente durante 28 dias. Foram utilizados trinta cães da raça Beagle com características semelhantes e mantidos sob o mesmo manejo e dieta. A medição da placa bacteriana e cálculo dentários foi realizada utilizando-se um método de análise computadorizada. 0 perfil fenólico do extrato de KGB foi analisado por HPLC-DAD. 0 extrato de KGB a 0,2\% mostrou eficácia no controle da formação de placa bacteriana em comparação com o grupo controle negativo, e de cálculo dentário em relação aos grupos controle negativo e positivo. Uma diferença significativa foi observada entre esses três grupos. Picos atribuídos a flavonoides e ácidos fenólicos foram identificados no cromatograma de HPLC-DAD do extrato de KGB. A presença de tais substâncias pode estar relacionada com a atividade observada. Os resultados demonstram que o tratamento com KGB é eficaz no controle da doença periodontal em cães, fornecendo novas perspectivas sobre as propriedades medicinais desta planta. $\mathrm{O}$ extrato de KGB tem uma utilização potencial como um agente suplementar em produtos farmacêuticos para a prevenção da doença periodontal.

TERMOS DE INDEXAÇÃO: Kalanchoe gastonis-bonnieri, extrato de plantas, biofilme bacteriano, cálculo dentário, cães, doença periodontal, cálculos dentários, placa bacteriana, flavonoides.

\section{INTRODUCTION}

Periodontal disease is caused by dental biofilm accumulation on teeth and adjacent structures (Lindhe et al. 1975). It has been identified as the most frequently occurring clinical condition in domestic dogs (Kyllar \& Witter 2005).

Human beings have used plants empirically since ancient times to treat health problems (Cragg et al. 2009). The World Health Organization (WHO) has estimated that in some Asian and African countries $80 \%$ of primary health care depends on plant-derived traditional medicines. Plant products are also consumed as medicines by people in developed countries (World Health Organization 2013). Traditional medicines need to be evaluated for safety and effectiveness, as well as scientific explanations concerning any collateral effects and their mechanisms of action (Booker et al. 2012, Luo et al. 2012, Shaw et al. 2012).

Kalanchoe species (Crassulaceae family) are widely used in traditional medicine in many regions of the world, especially India, Africa, China and Brazil due to their beneficial effects on inflammations, wounds and abscesses (Yadav \& Dixit 2003, Nguelefack et al. 2004). Flavonoids seem to be the most important compounds in the Kalanchoe species if we consider the bioactive substances isolated in bioguided studies (Costa et al. 2008).

The species Kalanchoe gastonis-bonnieri (Raym-Hamet et E.P. Perrier) (here denominated KGB) (Beltrán et al. 2003) is used in folk medicine for the treatment of genitourinary infection and as a vaginal contraceptive (Ososki et al. 2002). The plant has also shown ability to affect spermatozoa motility, viability and sperm density, and to significantly decrease carnitine and sialic acid content in the caudal epididymal plasma (Beltrán et al. 2003). The KGB extract has also exhibited in vitro antimicrobial activity on oral cavity bacteria (Menezes 2006) and antifungal activity 2011). Recently, from the leaf juice of KGB were isolated the new flavonoid quercetin 3-O- $\alpha$-rhamnopyranoside-7-O- $\beta$-D-glucopyranosyl-( $1 \rightarrow 3)$ - $\alpha$-L-rhamnopyranoside, as well as vicenin- 2 , a $C$-glycosyl flavone (Costa et al. 2015).

From the standpoint of dentistry, medicinal plants have been poorly studied. They could be a source of phytopreparations for the treatment and prevention of periodontal disease, or even for post-operatory therapy in classic surgical approach. These natural alternatives could reduce the need for surgical treatment, and cost of therapy. Also they could reduce the emergence of bacterial strains resistant to antibiotics and their side effects.

In the search for a new natural product against periodontal disease, this study aimed to evaluate the effect of an aqueous extract of Kalanchoe gastonis-bonnieri leaves on the dental plaque and calculus of dogs. Measurements were carried out using a computerized analytical method.

\section{MATERIALS AND METHODS}

The Bioethics Committee of the Veterinary Medical and Animal Science Faculty at the University of São Paulo (Protocol Number 1782/2009), and the Ethics Committee of the Veterinary Institute, at the Federal Rural University of Rio de Janeiro (Protocol Number 23083.000380/2008-71) duly authorized this experimental study.

Plant material. Kalanchoe gastonis-bonnieri specimens were cultivated in a residential garden in Rio de Janeiro, Brazil. Leaves from various specimens without any flowers were collected early in the morning in May, 2009. A voucher of a flowering specimen (RGA 31592) was deposited at the herbarium of the Botanical Department of the Institute of Biology, at the Federal University of Rio de Janeiro.

Plant extraction. Fresh leaves (448.57 g) of KGB were triturated in a blender with distilled water at $10 \%(\mathrm{w} / \mathrm{v})$. After filtration on cotton, a light-yellow aqueous preparation (KGB extract) was obtained. An aliquot corresponding to $100 \mathrm{~mL}(0.2 \mathrm{~g})$ of this extract was separated and lyophilized for chemical analysis. The KGB extract was prepared at the Laboratory of Chemistry of Bioactive Natural Products - LPN, Bio (Institute of Research on Natural Products - IPPN, UFRJ).

HPLC-DAD analysis. HPLC-DAD analysis was performed on a Shimadzu liquid chromatograph LC-10AD with a diode-array wavelength SPD-M10VP detector, using a Merck reverse-phase column C-18 (5 $\mu \mathrm{m}, 250 \mathrm{~mm}, 2.5 \mathrm{~mm})$. The mobile phase consisted of water containing $0.1 \%$ acetic acid (eluent A) and acetonitrile (eluent B). The solvent gradient used was: 0-5 min $(100-80 \% \mathrm{~A})$, $5-10$ min $(80-78 \%$ A), $10-25$ min $(78-75 \%$ A), 25-30 min (75$70 \%$ A), 30-35 min (70-40\% A), 35-40 min (40-30\% A), 40-50 min (30-20\% A), 50-60 min (20-0\% A); 60 min of total run time. The HPLC-DAD analysis was performed after dilution of $10 \mathrm{mg}$ of the extract in $1 \mathrm{~mL}$ of deionized water. $20 \mu \mathrm{L}$ of the extract were injected and the flow elution was $1 \mathrm{~mL} / \mathrm{min}$. The absorbance was monitored between 200 and 500nm. HPLC-DAD analyses were carried out at the Institute of Research on Natural Products, UFRJ, Brazil.

Animals. Thirty male and female Beagle dogs, from 12 to 60 months old and weighing between 10 to $15 \mathrm{~kg}$ were selected from the experimentation kennel of the Laboratory of Experimental Chemotherapy in Veterinarian Parasitology, Department of Animal Parasitology at the Federal Rural University of Rio de Janeiro.

All dogs in the study presented normal mesocephalic occlusion, full dentition, and presence of periodontal disease until sta- 
ge two (American Veterinary Dental College 2012). All dogs exhibited varying degrees of plaque and calculus accumulation.

Dogs were assigned randomly into three groups $(n=10)$ : The experimental group received $\mathrm{KGB}$ extract at $0.2 \%$, the positive control group received $0.12 \%$ chlorhexidine gluconate, and the negative control group received $0.9 \%$ saline solution. Each treatment was administered daily ( $10 \mathrm{~mL}$ of solution), topically in the mouth.

Throughout the 28-days of the clinical trial, dogs were fed commercial extruded pellets and water ad libitum. On day zero, all dogs were pre anesthetized with acepromazine $\left(0.1 \mathrm{mg} . \mathrm{kg}^{-1} i . v\right.$. $)$ and morphine (0.5mg.kg ${ }^{1}$ i.m.) before receiving dental scaling/polishing under general inhalation anesthesia. Propofol (5mg. $\mathrm{kg}^{1}$ i.v. $)$ was used for the induction of anesthesia, after this the general inhalation anesthesia was maintained with isoflurane $\left(30 \mathrm{~mL} \cdot \mathrm{kg}^{1}\right)$ vaporized with $100 \%$ oxygen (Fantoni \& Cortopassi 2002). The treatment began with the administration of $10 \mathrm{~mL}$ of the solution designated for each respective group one day after the dental scaling/polishing.

Plaque and calculi score assessments. Dental plaque of all dogs was disclosed with an aqueous solution of eosin $2 \%$ on the 7 th day and calculi on the 28th day (Veterinary Oral Health Council 2012). Plaque and calculi scores in both experiments were assessed by means of a computerized analysis accumulation technique. Twenty-two teeth were scored in each dog: maxillary left and right third incisors, canines, first, second, third and fourth premolar teeth; and, the mandibular left and right canines, second, third, fourth premolar and the first molar teeth (Logan \& Boyce 1994).

The computerized analysis accumulation technique (Abdalla et al. 2009) was carried out according to the following method: digital photographs of the oral cavity of each animal were taken to obtain the percentage of area affected by plaque (\% PB) and calculus (\% C), as well as the plaque area index (PAI) and the calculus area index (CAI) (Table 1). The digital images were taken before and after disclosed with an aqueous solution of eosin $2 \%$. A millimeter rule was placed to avoid errors due to distortion and to aid the calibration of linear measurements and calculation of tooth areas in the images. The digital images were analyzed with the aid of computer programs: GIMP 2.6.117, to treat the image; Image ${ }^{8}$ to obtain the measurements; and Broffice.org Calc ${ }^{9}$, to obtain the percentages of teeth surface affected by plaque or calculus relatively to the total area of each tooth (Abdalla et al. 2009).

The image analyzer was blind to the different treatments of the dogs when assessing plaque and calculus accumulation. Statistical analyses were performed on the results using the Student's $t$-test to compare the three groups. A value of $\mathrm{p}<0.05$ was considered significant (Hennet 2002).

GIMP2.6.11, computer program available at www.gimp.org on 10/08/2011.

${ }^{8}$ IMAGE J, computer program available at www.rsb.info.nih.gov/ij/ on 10/01/2007.

${ }^{9}$ Broffice.org Calc, computer program available at www.broffice.org on 10/01/2007.8.

Table 1. Calculus and plaque index system modified from Logan and Boyce (1994)

\begin{tabular}{cc}
\hline Index & \% of buccal tooth surface affected \\
\hline 0 & 0 \\
1 & $<0$ to $<25$ \\
2 & $\leq 25$ to $<50$ \\
3 & $\leq 50$ to $<75$ \\
4 & $75 \leq \mathrm{a} \leq 100$
\end{tabular}

Biochemical analyses. To assess any possible toxic effects of the KGB extract, biochemical analyses were performed comparing the experimental group before and after treatment with the KGB extract. Genesi Laboratory (Rio de Janeiro, RJ, Brazil) carried out the analyses of creatinine, urea, aspartate aminotransferase, alanine aminotransferase, and alkaline phosphatase of the dogs (Melo et al. 2006). The statistical analyses were performed using the Student's $t$-test as described above (Shaw et al. 2012).

\section{RESULTS \\ Chemical profile by HPLC-DAD}

Four major peaks attributed to phenolic substances were identified in the HPLC-DAD chromatogram of the KGB extract, as shown in Figure 1. Based on the retention times and UV absorbance spectra of each peak, the chemical classes of these phenolic substances were identified as shown in Table 2. The two flavonoids previously isolated by our group from KGB extract were identified based on retention time and confirmed by co-injection with these reference standards.

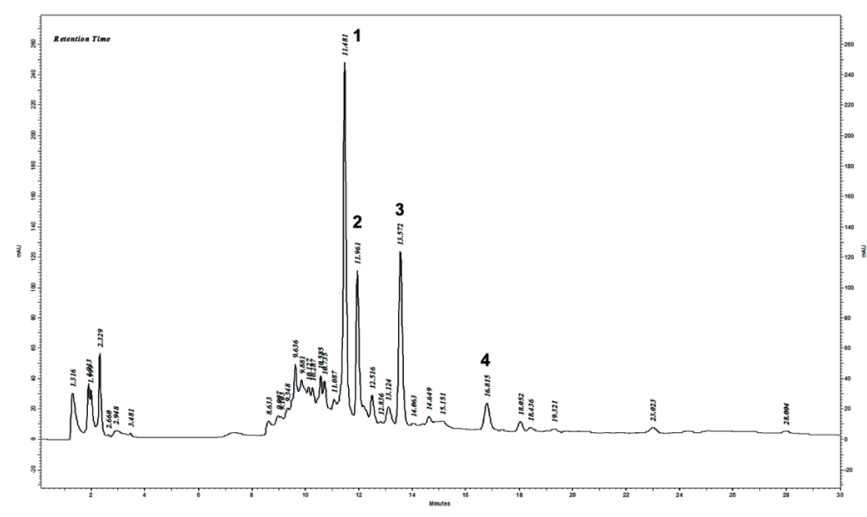

Fig.1. HPLC-DAD chromatogram $(254 \mathrm{~nm})$ of the aqueous extract from Kalanchoe gastonis-bonnieri leaves (0-30 min).

Table 2. Major phenolic compounds detected in the KGB leaf extract

\begin{tabular}{|c|c|c|c|c|}
\hline Peak & $\begin{array}{l}\text { Retention } \\
\text { time (min) }\end{array}$ & $\begin{array}{l}\lambda \max \\
(\mathrm{nm})\end{array}$ & $\begin{array}{l}\text { Area } \\
(\%)\end{array}$ & Chemical class \\
\hline 1 & 11.5 & 265 & 21.7 & Hydroxybenzoic acid derivative \\
\hline 2 & 12.0 & 290 & 10.7 & Hydroxybenzoic acid derivative \\
\hline 3 & 13.6 & 271,335 & 11.4 & Vicenin-2 \\
\hline 4 & 16.8 & 255,349 & 2.2 & $\begin{array}{l}\text { Quercetin 3-0- } \alpha \text {-rhamnoside-7-O- } \beta \text {-D- } \\
\text { glucosyl- }(1 \rightarrow 3)-\alpha \text {-L-rhamnoside }\end{array}$ \\
\hline
\end{tabular}

\section{Evaluation of plaque and calculus scores}

The results of the dogs in the experimental group (KGB) had statistically significantly lower plaque $(P=0.01)$ and calculus $(P=0.0164)$ scores when compared to the negative control group, on 7th day and 28th day, respectively. Also the dogs treated with KGB showed lower calculus scores $(P=0.026)$ when compared with dogs of the positive control group. The means of plaque and calculus index score were $20 \%$ and $19 \%$ inferior for the experimental group compared with the negative control group, and $6.1 \%$ and $22 \%$ lower than the positive control group, respectively (Table 3). 
Table 3. Comparison of plaque and calculus scores of the computerized assessment (Abdalla et al. 2009) of areas of buccal surface with modified Logan and Boyce scores (1994) after use of the treatment protocols

\begin{tabular}{|c|c|c|c|}
\hline & \multicolumn{3}{|c|}{ Groups } \\
\hline & $\begin{array}{l}\text { Positive } \\
\text { control }^{a}\end{array}$ & $\begin{array}{l}\text { Negative } \\
\text { control }^{\mathrm{b}}\end{array}$ & Experimental \\
\hline Number of dogs & \multirow[t]{2}{*}{10} & \multirow[t]{2}{*}{10} & \multirow[t]{2}{*}{10} \\
\hline 1 Week Mean Plaque & & & \\
\hline Score $\operatorname{PAI}^{\mathrm{d}}\left(\mathrm{SD}^{\mathrm{e}}\right)$ & \multirow[t]{2}{*}{$2.082(0.16)$} & \multirow[t]{2}{*}{$2.436(0.5)$} & \multirow[t]{2}{*}{$1.955(0.1)$} \\
\hline 4 Weeks Mean Calculus & & & \\
\hline \multirow[t]{2}{*}{ Score $\mathrm{CAI}^{\mathrm{f}}\left(\mathrm{SD}^{\mathrm{e}}\right)$} & $2.25(0.2)$ & $2.178(0.48)$ & $1.76(0.09)$ \\
\hline & \multicolumn{3}{|c|}{ Comparison vs. Negative Control } \\
\hline$P$ Value between treatments $\mathrm{P}$ & 0.1352 & - & $0.01 \mathrm{~g}$ \\
\hline$P$ Value between treatments DC & C 0.7831 & - & $0.0164 \mathrm{~g}$ \\
\hline Plaque reduction (\%) & 14.5 & - & 20 \\
\hline \multirow[t]{2}{*}{ Calculus reduction (\%) } & -3 & - & 19 \\
\hline & \multicolumn{3}{|c|}{ Comparison vs. Positive Control } \\
\hline$P$ Value between treatments $\mathrm{P}$ & - & - & 0.26 \\
\hline$P$ Value between treatments DC & - & - & $0.026^{\mathrm{g}}$ \\
\hline Plaque reduction (\%) & - & - & 6.1 \\
\hline Calculus reduction (\%) & - & - & 22 \\
\hline
\end{tabular}

a The positive control used a rinse with chlorhexidine $0.12 \%$ a plaque-control antiseptic, ${ }^{\mathrm{b}}$ The negative control group used a rinse with physiologic solution $0.9 \%$, ${ }^{\mathrm{c}}$ The experimental group used a rinse with $0.2 \%$ of Kalanchoe gastonis-bonnieri extract, ${ }^{\mathrm{d}} \mathrm{PAI}=$ plaque area index, ${ }^{\mathrm{e}} \mathrm{SD}=$ Standard deviation, ${ }^{\mathrm{f}} \mathrm{CAI}=$ calculus area index, ${ }^{\mathrm{g}}$ Significant difference.

Table 4. Results of Student $t$ tests comparing serum hepatic and renal enzymes, before and after treatment with Kalanchoe gastonis-bonnieri extract

\begin{tabular}{cccccc}
\hline Enzymes & $\begin{array}{c}\text { Zero day } \\
\text { average }\end{array}$ & $\begin{array}{c}28 \text { day } \\
\text { average }\end{array}$ & $\begin{array}{c}\text { Zero day } \\
\text { SD }\end{array}$ & $\begin{array}{c}28 \text { days } \\
\text { SD }\end{array}$ & Student's $t$ - test \\
\hline
\end{tabular}

\begin{tabular}{lccccc}
\hline $\begin{array}{l}\text { ALP-AMPa } \\
\text { UI/L }\end{array}$ & 68.4 & 59.2 & 60.96 & 65.77 & $\mathrm{P}=0.3439$ \\
$\begin{array}{l}\text { ALT } \\
\text { UI/L }\end{array}$ & 60.9 & 74.1 & 50.19 & 81.23 & $\mathrm{P}=0.5160$ \\
$\begin{array}{l}\text { AST } \\
\text { UI/L }\end{array}$ & 22.2 & 26.7 & 6.32 & 11.48 & $\mathrm{P}=0.1311$ \\
$\begin{array}{l}\text { CREATININE } \\
\text { mg/dL }\end{array}$ & 0.84 & 0.81 & 0.21 & 0.21 & $\mathrm{P}=0.3434$ \\
$\begin{array}{l}\text { UREA } \\
\text { mg/dL }\end{array}$ & 30.6 & 34.5 & 13.03 & 22.12 & $\mathrm{P}=0.3630$ \\
$\begin{array}{l}\text { alkaline phosphatase, } \\
\text { transferase. }\end{array}$
\end{tabular}

\section{Biochemical analyses}

The values of creatinine, urea, aspartate aminotransferase, alanine aminotransferase, and alkaline phosphatase of the experimental group were compared between before and after treatment with KGB extract. There was no significant difference in the biochemical analyses for dogs before and after treatment with the KGB extract (Table 4).

\section{DISCUSSION}

Plants have been used empirically by humans since ancient times to treat health problems (Cragg et al. 2009, World Health Organization 2013). Based on the well-known pharmacological properties of natural compounds from plant origin we looked for a natural anti plaque agent to prevent periodontal disease in dogs.

The most frequently occurring pathological condition in domestic dogs is periodontal disease. Our study aimed to find an effective agent against plaque formation since this is the etiological agent of periodontal disease (Löe 1967, Varoni et al. 2012). Preventing plaque formation is the key factor in thwarting periodontal disease (Lindhe et al. 1975, Klukowska et al. 2012). As KGB has been shown to have antimicrobial activity against canine oral cavity bacteria in in vitro assays we assessed the effect of this extract in in vivo trials, with the participation of 30 Beagle dogs distributed into three groups of 10 animals.

In this study, the staining of bacterial plaque was made by using an aqueous solution of $2 \%$ eosin. We opted for the eosin in this study because it does not present antimicrobial activity and is easily removed from the tooth surface (Silva et al. 2002). These features make eosin an advantageous option for assessing specific products with antiplaque action. Furthermore, it was found that rinsing the oral cavity to remove the aqueous eosin $2 \%$ did not influence the results, since only materia alba and food debris (Schwartz et al. 1971) can be removed by mechanical action of a water jet. The plaque (Mandel 1966) as well as dental calculus were not affected (Harvey \& Emily 1993).

Another issue that involves mechanical action on the materia alba and plaque is the dry food chewing. This effect was minimized in this study because dogs had the same breed and showed the same type of occlusion, both factors contributing to the reduction of individual variations. Additionally, dogs mostly chew only a small portion of the feed grain they eat, because of their instinct to swallow large portions as quickly as possible, thus consuming the greatest amount of food in a minor time. Still with the objective of minimizing the mechanical action of the oral mouthwash, the negative control group received a saline $0.9 \%$ washing jet, which removed only materia alba and not the plaque, as in the other groups of animals used.

According to the standards set by the Veterinary Oral Health Council (Veterinary Oral Health Council 2012) the minimum difference required for the mean mouth scores (average of all teeth measured for all animals in each group) should be at least $10 \%$ reduction for both dental plaque and for calculus when comparing the experimental and negative control groups. In this study, a $20 \%$ plaque reduction and a 19\% dental calculus reduction was observed when the experimental group was compared with the negative control group. Also dental calculus was reduced by $22 \%$ in the experimental group compared with the positive control group, while plaque was only reduced by $6.1 \%$ compared with the positive control. The same occurred in an in vivo study with dogs (Pieri et al. 2010) where Copaifera officinalis (Fabaceae) was used in the experimental group, demonstrating the potential of medicinal plants for plaque reduction.

The KGB extract has been shown to be useful in controlling the oral microbiota of dogs. The presence of phenolic acids and flavonoids in the KGB extract (Correa 2010), as shown in Figure 1 and Table 2, could be related to the antibacterial activity and its efficacy on plaque formation when compared with negative control group.

Phenolic-rich plant extracts and fractions have shown 
anti-plaque and anticariogenic activity in many studies (Yanagida et al. 2000, Thimothe et al. 2007, Tomczyk et al. 2010, 2011, Yano et al. 2012, Tomczyk et al. 2013). In some of them, it was possible to establish a positive correlation between the phenolic content and anti-plaque activity (Tomczyk et al. 2011, Yano et al. 2012).

A mouth rinse containing phenolic compounds was evaluated in a placebo-controlled, double-blind study for six months (Grossman et al. 1989). Although less effective than chlorhexidine rinse, the phenolic agents provided significant reductions in plaque (24\%) when compared to placebo, showing that they are promising therapeutic agents for these pathologies (Grossman et al. 1989). A similar result was observed in a two-week study with a commercial mouth rinse containing phenols. This product reduced not only plaque formation but also the development of gingivitis in the volunteers when compared to placebo, but was less effective than chlorhexidine rinse in the inhibition of plaque formation (Sekino \& Ramberg 2005).

The presence of phenolic substances in KGB could justify at least partially the results obtained from the KGB extract. Flavonoids, the most important compounds in Kalanchoe genus, probably contribute to the activities observed in this study.

Flavonoids possess antibacterial and anti-plaque formation activities as has already been reported by other authors (Sakagami et al. 1999, Sato et al. 2003, Shu et al. 2011). Flavonoids are a group of polyphenolic compounds from vegetal origin, which have a wide spectrum of biological activities, including antimicrobial (Cushnie \& Lamb 2011), anti-inflammatory (Cazarolli et al. 2008) and immunomodulatory action (Paszkiewicz et al. 2012).

The inhibitory growth effect of these polyphenols on oral cariogenic bacteria such as Streptococcus and Actinomyces was demonstrated in vitro. Flavonoids belonging to the flavanone subclass showed great activity at concentrations of 1.56 to $6.25 \mu \mathrm{g} / \mathrm{mL}$ (Tsuchiya et al. 1994).

Flavonoids can also contribute to the prevention of periodontal disease. Dental plaque and calculus are considered to be the main causes of these lesions (Cai et al. 2008, Varoni et al. 2012). A dentifrice containing flavonoids showed to be beneficial when tested in rats against gingival oxidative stress and periodontal inflammation (Maruyama et al. 2011). In a clinical study carried out on human volunteers, the local application of green tea catechins was effective in improving the periodontal status. These phenolic compounds have been shown to have a bactericidal effect in vitro and in vivo (Hirasawa et al. 2002).

The beneficial effect of flavonoids on caries, gingivitis, periodontal disease, oral aphthae and other oral pathologies has already been confirmed in pre-clinical studies against these common oral pathologies (Varoni et al. 2012).

The potential contribution of phenolic acids for the anti-plaque activity of KGB cannot be excluded. However, there are few studies on the activity of these substances on bacterial plaque formation. In another study, phenolic acids were not able to inhibit the enzymes that are important for the synthesis of glucans, a biofilm constituent produced by Streptococci (Yanagida et al. 2000).
The safety and collateral effects of KGB extract were also investigated in this work (Booker et al. 2012, Luo et al. 2012, Shaw et al. 2012). No statistically significant differences were observed in the biochemical parameters evaluated in the blood serum of dogs. However, it is important to note that this study duration was short.

In a study with male rats using a KGB aqueous extract, Beltrán et al. (2003) found that $11 \mathrm{~g} / \mathrm{kg}$ was the lethal dose for $50 \%$ of animals. This extract produced reversible infertility at doses of 300 and $150 \mathrm{mg} / \mathrm{kg}$ (Beltrán et al. 2003). In the present study, dogs with an average weight of 12.5 $\mathrm{kg}$ were treated daily with $20 \mathrm{mg}$ of the KGB extract $(10 \mathrm{ml}$ of a $0.2 \%$ solution). This much lower amount of KGB extract administered orally to dogs is very far from the lethal dose observed for rats. When compared to the doses used by these authors, the total amount administered during the treatment is not likely to produce the above mentioned effect, even considering that part of the KGB extract could be absorbed by dog's oral mucosa. However, further studies are necessary to assess the effects of KGB on dog's fertility.

Some toxicological data for other medicinal species of Kalanchoe have been reported. An extract from K. pinna$t a$, whose leaves are widely used for healing wounds, was toxicologically evaluated in vivo. Mice orally treated with the $K$. pinnata aqueous leaf extract for 30 days showed no changes in levels of alanine-aminotransferase (ALT), aspartate-aminotransferase (AST), urea and alkaline phosphatase. Additionally, a 36-year-old man under treatment for leishmaniasis with this plant extract for a period of 14 days showed no changes in serum toxicological parameters or adverse reactions (Torres-Santos et al. 2003).

$K$. brasiliensis leaf juice produced no acute toxicity in mice at doses from 0.25 to $5 \mathrm{~g} / \mathrm{kg}$, administered intraperitoneally (Mourão et al. 1999). Similar results were observed for an aqueous extract of $K$. integra at an oral dose of $5 \mathrm{~g} / \mathrm{kg}$, which appeared to be non-toxic to mice (Antwi et al. 2013).

In all cases, we must be careful in the indiscriminate use of medicinal plants because they may present undesirable side effects. Furthermore, the study of safe conditions should be performed for a long-term use of KGB against dental plaque and calculus to guarantee that this treatment does not cause undesirable local and systemic effects (Shaw et al. 2012), as has been described for chlorhexidine and triclosan (Antwi et al. 2013, Lee et al. 2004, Salgado et al. 2006). However, our findings indicate a promising therapeutic application of KGB species in oral pathologies.

\section{CONCLUSIONS}

A single daily rinse with KGB extract at $0.2 \%$ showed efficacy in controlling the formation of dental plaque compared to the negative control group, and dental calculus in relation to negative and positive control groups. There was a significant difference for these three groups.

Thus, the KGB extract has a potential use as a supplemental agent in pharmaceutical products for the prevention of periodontal disease.

Our findings could encourage further studies in view of a potential utilization in human periodontal diseases. A 
natural medicinal plant that is widely available, with the profile of an anti-calculi and anti-biofilm dental agent is a very promising alternative for the pharmaceutical industry.

Further studies are needed to monitor the absence of long-term side effects of a KGB extract, as well as the understanding of the mechanism of this phytopreparation in the impairment of the bacterial biofilm and dental calculus formation.

Acknowledgements.- We thank Genesi Laboratory. S.L.A. Abdalla and L.M. Casanova are grateful to CNPq, and M.A.S. Coutinho to CAPES for fellowships.

\section{REFERENCES}

Abdalla S.L., Silva M.F.A., Pereira A.R.C., Azevedo F.D., Fernandes J.I., Minomo G.P. \& Botelho R.P. 2009. Computer quantification for the evaluation of dental plaque and dental calculus index in the digital image of vestibular surface of the teeth of dogs (in Portuguese). Pesq. Vet. Bras. 29(8):666-672.

Antwi D.A., Asiedu-Gyekye I.J., Awortwe C., Adjei S. \& Addo P. 2013. A single oral high dose toxicity study of Kalanchoe integra var.crenata (Andr.) Cuf leaf extract in ICR mice: histopathological and biochemical changes. Int. J. Med. Pharm. Sci. 3(9):8-17.

AVDC 2012. Veterinary Dental Nomenclature. American Veterinary Dental College. Available from <http://www.avdc.org/Nomenclature.pdf>

Beltrán M.L.M., Pérez A.M.P., Sánchez A.G. \& Ruiz L.H. 2003. Male rat infertility induction/spermatozoa and epididymal plasma abnormalities after oral administration of Kalanchoe gastonis-bonnieri natural juice. Phytother. Res. 17:315-319.

Booker A., Johnston D. \& Heinrich M. 2012. Value chains of herbal medicines - research needs and key challenges in the context of ethnopharmacology. J. Ethnopharmacol. 140:624-633.

Cai X., Li C., Du G. \& Cao Z. 2008. Protective effects of baicalin on ligature-induced periodontitis in rats. J. Periodontal Res. 43(1):14-21.

Cazarolli L.H., Zanatta L., Alberton E.H., Figueiredo M.S., Folador P., Damazio R.G., Pizzolatti M.G. \& Silva F.R. 2008. Flavonoids: prospective drug candidates. Mini Rev. Med. Chem. 8(13):1429-1440.

Correa M.F.P. 2010. Kalanchoe gastonis-bonnieri R. Hamet \& H. Perrier (Crassulaceae): composição flavonoídica e potencial terapêutico em hiperplasia prostática benigna. Tese de Doutorado, Centro de Ciências da Saúde, Universidade Federal do Rio de Janeiro, RJ. 127p.

Costa S.S., Muzitano M.F., Camargo L.M.M. \& Coutinho M.A.S. 2008. Therapeutic potential of Kalanchoe species: Flavonoids and other secondary metabolites. Nat. Prod. Commun. 3:2151-2164.

Costa S.S., Corrêa M.F.P. \& Casanova L.M. 2015. A new triglycosyl flavonoid isolated from leaf juice of Kalanchoe gastonis-bonnieri (Crassulaceae). Nat. Prod. Commun. 10(3):433-436.

Cragg G.M., Grothaus P.G. \& Newman D.J. 2009. Impact of natural products on developing new anti-cancer agents. Chem. Rev. 109:3012-3043.

Cushnie T.P.T. \& Lamb A.J. 2011. Recent advances in understanding the antibacterial properties of flavonoids. Int J. Antimicrob. Agents 38(2):99-107.

Fantoni D.T. \& Cortopassi S.R.G. 2002. Anesthetic protocols (in Portuguese). Roca, São Paulo. 209p.

Grossman E., Meckel A.H., Isaacs R.L., Ferreti G.A., Sturzenberger O.P., Bollmer B.W., Moore D.J., Lijana R.C. \& Manhart M.D. 1989. A clinical comparison of antibacterial mouthrinses: effects of chlorhexidine, phenolics, and sanguinarine on dental plaque and gingivitis. J. Periodontol. 60(8):435-440.

Harvey C.E. \& Emily P.P. 1993. Small Animal Dentistry. Mosby, Missouri. $413 p$.

Hennet P. 2002. Effectiveness of a dental gel to reduce plaque in beagle dogs. J. Vet. Dent. 19(1):11-14.

Hirasawa M., Takada K., Makimura M. \& Otake S. 2002. Improvement of periodontal status by green tea catechin using a local delivery system: a clinical pilot study. J. Periodontal Res. 37(6):433-438.
Klukowska M., Grender J.M., Goyal R., Qaqish J. \& Biesbrock A.R. 2012. 8-week evaluation of anti-plaque and anti-gingivitis benefits of a unique multi-directional power toothbrush versus a sonic control toothbrush. Am. J. Dent. 25(Spec. Issue A):27A-32A.

Kyllar M. \& Witter K. 2005. Prevalence of dental disorders in pet dogs. Vet. Med. 50(11):496-505.

Lee S.S., Zhang W. \& Li Y. 2004. The antimicrobial potential of 14 natural herbal dentifrices: results of an in vitro diffusion method study. J. Am. Dent. Assoc. 135:1133-1141.

Lindhe J., Hamp S.E. \& Loe H. 1975. Plaque induced periodontal disease in beagle dogs: 4-year clinical, roentgenographical and histometrical study. J. Periodontal Res. 10:243-255.

Löe H. 1967. The gingival index, the plaque index and the retention index systems. J. Periodontol. 38:610-616.

Logan E.I. \& Boyce E.N. 1994. Oral health assessment in dogs: parameters and methods. J. Vet. Dent. 11(2):58-63.

Luo H., Li Q., Flower A., Lewith G. \& Liu J. 2012. Comparison of effectiveness and safety between granules and decoction of Chinese herbal medicine: a systematic review of randomized clinical trials. J. Ethnopharmacol. 140:555-567.

Maruyama T., Tomofuji T., Endo Y., Irie K., Azuma T., Ekuni D., Tamaki N., Yamamoto T. \& Morita M. 2011. Supplementation of green tea catechins in dentifrices suppresses gingival oxidative stress and periodontal inflammation. Arch. Oral Biol. 56(1):48-53.

Mandel I.D. 1966. Dental plaque: nature, formation and effects. J. Periodontol. 37:357-367.

Melo A.F.M., Albuquerque M.M., Silva M.A.L., Gomes G.C., Cruz I.S.V., Leite V.R. \& Higino J.S. 2006. Evaluation of the subchronic toxicity of the crude dry extract of Anacardium occidentale Linn. in dogs (in Portuguese). Acta Scient. Health Sci. 28(1):37-41.

Menezes M.C. 2006. Avaliação "in vitro" da atividade antimicrobiana de extratos de plantas sobre a microbiota da cavidade oral de cães. Dissertação de Mestrado em Medicina Veterinária, Faculdade de Medicina Veterinária, Universidade Federal Rural do Rio de Janeiro, Seropédica, RJ. 42p.

Mourão R.H., Santos F.O., Franzotti E.M., Moreno M.P. \& Antoniolli A.R. 1999. Antiinflammatory activity and acute toxicity (LD50) of the juice of Kalanchoe brasiliensis (Comb.) leaves picked before and during blooming. Phytother. Res. 13:352-354.

Nguelefack T.B., Fotio A.L., Watcho P., Wansi S.L., Dimo T. \& Kamanyi A. 2004. Analgesic properties of the aqueous and ethanol extracts of the leaves of Kalanchoe crenata (Crassulaceae). Phytother. Res. 18:385-388.

Ososki A.L., Lohr P., Reiff M., Balick M.J., Kronenberg F., Fugh-Berman A. \& O'Connor B. 2002. Ethnobotanical literature survey of medicinal plants in the Dominican Republic used for women's health conditions. J. Ethnopharmacol. 79(3):285-298.

Paszkiewicz M., Budzynska A., Rozalska B. \& Sadowska B. 2012. The immunomodulatory role of plant polyphenols. Postepy Hig. Med. Dosw. 66:637-646.

Pieri F.A., Mussi M.C., Fiorini J.E. \& Schneedorf J.M. 2010. Clinical and microbiological effects of copaiba oil (Copaifera officinalis) on dental plaque forming bacteria in dogs (in Portuguese). Arq. Bras. Med. Vet. Zootec. 62(3):578-585.

Sakagami H., Oi T. \& Satoh K. 1999. Prevention of oral diseases by polyphenols: a review. In Vivo 13(2):155-171.

Salgado A.D.Y., Maia J.L., Pereira S.L.S., de Lemos T.L. \& Mota O.M. 2006. Antiplaque and antigingivitis effects of a gel containing Punica granatum Linn extract: a double-blind clinical study in humans. J. Appl. Oral Sci. 14:162-166.

Sato M., Tanaka H., Fujiwara S., Hirata M., Yamaguchi R., Etoh H. \& Tokuda C. 2003. Antibacterial property of isoflavonoids isolated from Erythrina variegata against cariogenic oral bacteria. Phytomedicine 10(5):427433.

Schwartz R.S., Massler M. \& Le Beau L.J. 1971. Gingival reactions to different types of tooth accumulated materials. J. Periodontol. 42(3):144-151. 
Sekino S. \& Ramberg P. 2005. The effect of a mouth rinse containing phenolic compounds on plaque formation and developing gingivitis. J. Clin. Periodontol. 32:1083-1088.

Shaw D., Graeme L., Pierre D., Elizabeth W. \& Kelvin C. 2012. Pharmacovigilance of herbal medicine. J. Ethnopharmacol. 140(3):513-518.

Shu Y., Liu Y., Li L., Feng J., Lou B., Zhou X. \& Wu H. 2011. Antibacterial activity of quercetin on oral infectious pathogens. Afr. J. Microbiol. Res. 5(30):5358-5361.

Silva C.H.L., Paranhos H.F.O. \& Ito I.Y. 2002. Evidenciadores de biofilme em prótese total: avaliação clínica e antimicrobiana. Pesq. Odontol. Bras. 16(3):270-275.

Thimothe J., Bonsi I.A., Padilla-Zakour O.I. \& KOO H. 2007. Chemical characterization of red wine grape (Vitis vinifera and Vitis interspecific hybrids) and pomace phenolic extracts and their biological activity against Streptococcus mutans. J. Agric. Food Chem. 55:10200-10207.

Tomczyk M., Pleszczyńska M., Wiater A. \& Granica S. 2013. In vitro anticariogenic effects of Drymocallis rupestris extracts and their quality evaluation by HPLC-DAD-MS ${ }^{3}$ analysis. Molecules 18:9117-9131.

Tomczyk M., Pleszczyńska M. \& Wiater A. 2010. Variation in total polyphenolics contents of aerial parts of Potentilla species and their anticariogenic activity. Molecules 15:4639-4651.

Tomczyk M., Wiater A. \& Pleszczyńska M. 2011. In vitro anticariogenic effects of aerial parts of Potentilla recta and its phytochemical profile. Phytother. Res. 25:343-350.
Torres-Santos E.C., da Silva S.A., Costa S.S., Santos A.P., Almeida A.P. \& Rossi-Bergmann B. 2003. Toxicological analysis and effectiveness of oral $\mathrm{Ka}$ lanchoe pinnata on a human case of cutaneous leishmaniasis. Phytother. Res. 17:801-803.

Tsuchiya H., Sato M., Inuma M., Yokoyama J., Ohyama M., Tanaka T., Takase I. \& Namikawa I. 1994. Inhibition of the growth of cariogenic bacteria in-vitro by plant flavanones. Experientia 50(9):846-849.

Varoni E.M., Lodi G., Sardella A., Carrassi A. \& Iriti M. 2012. Plant polyphenols and oral health: old phytochemicals for new fields. Curr. Med. Chem. 19:1706-1720.

VOHC 2012. The VOHC Seal of Acceptance. Veterinary Oral Health Council. Available from <http://www.vohc.org> Accessed on January 22, 2012.

WHO 2013. World Health Organization. Available from <http://www.who. int/mediacentre/factsheets/fs134/en/> Accessed on March 10, 2013.

Yadav N.P. \& Dixit V.K. 2003. Hepatoprotective activity of leaves of Kalanchoe pinnata Pers. J. Ethnopharmacol. 86:197-202.

Yanagida A., Kanda T., Tanabe M., Matsudaira F. \& Oliveira-Cordeiro I.Q. 2000. Inhibitory effects of apple polyphenols and related compounds on cariogenic factors of mutans streptococci. J. Agric. Food. Chem. 48:56665671.

Yano A., Kikuchi S., Takahashi T., Kohama K. \& Yoshida Y. 2012. Inhibitory effects of the phenolic fraction from the pomace of Vitis coignetiae on biofilm formation by Streptococcus mutans. Arch. Oral Biol. 57:711719. 